\title{
Micro Teaching to Improve Teaching Method: An Analysis on Students' Perspectives
}

\author{
Imran Mahmud, Shahriar Rawshon \\ SeniorLecturer,Daffodil International University,Bangladesh \\ Research Assistant, IUBAT, Bangladesh
}

\begin{abstract}
Experimental teaching and learning method have been consistently demonstrated to achieve better outcomes than traditional lecture based technique. Micro teaching is a concept of developing the teaching method according a developing media like video tapping and a combination of student feedback. However the focus of this paper is not to provide a history of microteaching as its usage mirrors in the educational framework what is dominated at the time. Our aim in this paper is project based learning, learning with technology and reflects a social constructivist approach where teachers' produced microteaching effective projects in a collaborative learning setting and this new way of teaching method increases the quality of higher education in a broader sense with the development of the student understanding level. The research method was designed analyzing different secondary data regarding with higher level teaching tools. The primary data is collected from an experimental design where the class participation of students of IUBAT, where students responded with the different questionnaires. According to the statistical analysis all data are evaluated and analysis basis on the feedback of the respondent. The findings of the paper state that microteaching can play a significant role in student education and can contribute to a great extent to the better understanding of the learning process and its complexities.
\end{abstract}

\section{Introduction}

Education has become a clear focus of attention for balancing the budget as a means of meeting school district needs by laying off or cutting teachers (Sterrett \& Imig, 2011). Instead of teacher shortages there is a constant call of teacher layoffs. This has been done through frozen pay raises, underfunding for supplies and technology, and a lack of funds for building upgrades. Where once teaching was the main focus for our children, it has now become a target for budget balancing.

Five years ago no one saw this coming - the focus on education as a reduction issue for spending. Those hit the hardest are -at-risk. students whose numbers are rising. Benchmarks accountability is increasing as well as the deteriorating conditions of school buildings infrastructure nationwide. With all this, everything must be done to maintain high quality education for our students through quality teachers without an excuse for a slowdown in growth for our educational development. The strength of our nation will be determined by the development through education of our future leaders. Microteaching is used in the field of therapy, (Mastromarino, R., 2004), to help convert theoretical knowledge into practical applications during interaction with patients. Five techniques were used: (1) role playing and video or audio recording, (2) self observational and/or supervision (monitoring), (3) reinforcement (dissonance), (4) re experimentation, and (5) practice of the acquired abilities. It shows people improve their performance using this method of teaching.

The United Kingdom used microtraining for managing and participating in group discussion (Martin, D., \& Campbell, B, (1999).

Recommendations were made by the Dearing Committee (1977) to develop student skills in universities and colleges in the area of communicative abilities. It was believed that the development of students' ability to communicate during their higher learning experience was necessary a quality education. The students viewing themselves on video proved were helpful in developing their skills."Microteaching is a method for training teachers where explicit use is made of the principle of feedback and where the teacher-learning situation remains limited with respect to:

The number of students to whom the lesson is given;

The duration of the lesson;

The extent of the lesson in terms of contents and didactic presentation".

According to Allen and Ryan (1969: 1-3) microteaching has the following characteristics:

(a) It is a real teaching situation.

(b) It reduces the complexity of the real classroom teaching situation in terms of the number of students, the amount of time and the amount of learning contents.

(c) It emphasizes training for mastery of teaching activities such as skills, techniques, methods, and curriculum selection. 
(d) It offers better control over practicing teaching activities because many factors easily can be manipulated to attain this greater degree of control in the training program.

(e) The feedback dimension is expanded considerably because the student can receive meaningful feedback immediately after his performance, and with the help of a variety of technological teaching media as well as observation and interaction-analysis instruments can take the opportunity to improve his performance in light of the feedback provided.

In summary, microteaching is an instrument for teacher training. If offers the student the opportunity to practice teaching activities under controlled and simulate circumstances such that the complexity of the real teaching situation.

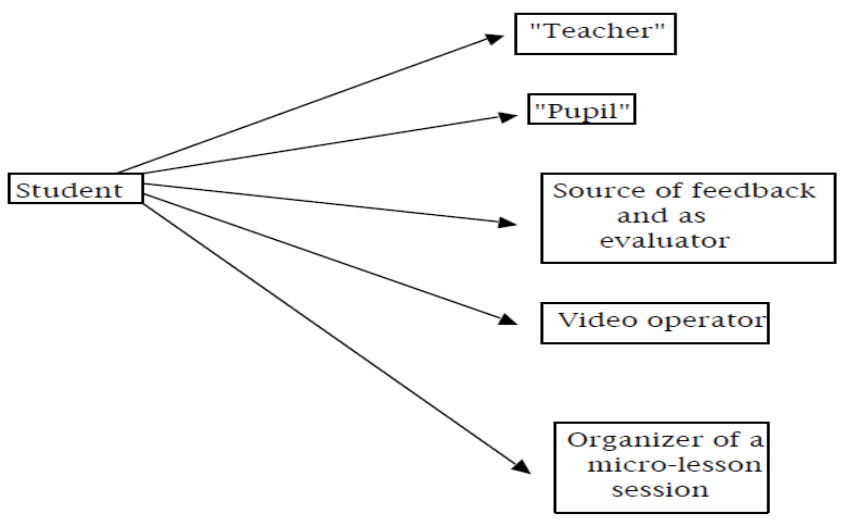

Fig 1: Functions of a student in Micro Teaching

\section{New Teachers}

During these difficult economic times, new teachers are being hired and face problems that they are not taught to handle in school (Sterrett \& Imig, 2011; Melnick \& Meister, 2008, \& Le Maistre \& Paré, 2010). Getting a degree, which includes paratica, internships, and work study programs, is not always enough to prepare new teachers for the classroom experience (Le Maistre \& Paré, 2010). Newcomers to the teaching profession must be prepared for the experience through a transition process.

Beginning teachers are new teachers who have been teaching for three years (Melnick \& Meister, 2008). The most serious problem areas for these teachers are: classroom discipline, motivating pupils, dealing with individual differences, assessing pupils' work, relations with parents, organization of class work, insufficient materials and supplies, and dealing with problems of individual pupils. Lesser problems are relations with colleagues, planning of lessons and schooldays; effective use of different teaching methods; awareness of school policies and rules; determining learning level of students; knowledge of subject matter, burden of clerical work, and relations with principals/administrators.

After completing university courses, teacher candidates are required to pass their practicum, reach an acceptable level of performance, and then become certified to teach (Le Maistre \& Paré, 2010). New teachers need help with coping strategies because of a lack of classroom problem solving strategies which is gained through experience. School leaders must recognize the gap between veteran and new teachers so that assistance can be given to help them gain the experience they need to be successful. Mentoring, technology, collaborative leadership, and working within professional organizations are four areas that were found to assist new teachers with gaining experience (Sterrett \& Imig, 2011).

According to Le Maistre and Paré (2009) factors explaining the increase in teachers` workload are greater societal expectations and lower societal recognition; greater accountability to parents and policy-makers; pedagogical and curriculum changes being implemented at an increasing rate; increased need for technological competence; increased demands beyond the pedagogical task; increasing diversity among students; and more administrative work (p. 3). Other problem areas for new teachers are (1) attrition caused by a lack of support as the main reason with what is expected and what is the realty of teaching; (2) problem solving is caused by new teachers not having the experience or knowledge of what to do find solutions; (3) inadequate or nonexistent mentoring; (4) satisficing is a construct that refers to strategy in decision making situations where the solution for the problem will work and one that the new teacher can live with (Le Maistre \& Paré, 2010).

Sterrett and Imig (2011) strongly support mentoring of new teachers by either a veteran teacher or colleague in the areas of classroom management, alignment of curriculum, and managerial minutia. Classroom management involved the new teacher learning to build a classroom community as well as being consistent with good communication skills. It requires new teachers learn the school or district's approach to classroom management rather than punitive structures. The alignment of curriculum involves the new teacher understanding the material 
and being sure it is appropriately paced for the age group. New teachers need either a mentor or veteran colleague to assist with the completion of forms, meeting deadlines, and protocols which can be overwhelming. Even though budgets are tight there are opportunities for the use of technology for engaging students through interactive lessons, communicating with parents, interacting with colleagues, and using underused resources. This can be accomplished through the use of SMART BoardTM, or a web site and communicating with parents using confidentiality with email, Skype, twitter. Using some of the classroom technology developed but not used because the United States has spent billions of dollars developing projects that were either not used, put on the shelf, or set aside for something newer or more up to date.

It is important that new teachers stay up with the latest trends in education and are aware of changes by continuing to learn. Becoming a collaborative leader is important and involves subject/grade level or district leadership; peer observations, and community leadership (Sterrett \& Imig, 2011). It is suggested that new teachers take on assignment by volunteering when given the opportunity with a veteran colleague review and validate what was done before final submission. Visiting colleagues will give a new teacher an opportunity to seek advice about pedagogy and working with students. Community leadership can be accomplished by volunteering at reading clinics, toy drive efforts, or working with tutoring through local organizations. Making contact with professional organizations can be accomplished through awareness of current policy issues, advocate through service, and sharing ideas. The new teachers of today will be the veteran educator of tomorrow. It is important that new teachers learn from more experienced colleagues. As new teachers gain experience they can pass on their new ideas.

The most serious problem for new teachers is classroom management which affect students learning Clement, 2010). Without proper training, it becomes easy for a new teacher to manage as they were managed or resort to other techniques they may have been told or seen. Some of the myths for classroom teaching are (1) you can be taught classroom management because it is something you have to learn, (2) begin firmly to show you are in charge, (3) when all else fails turn the lights on and off to get the students attention, (4) keep a stern look by not smiling, (5) single out the student causing all the problems and focus on them by making an example to scare others. Teaching classroom management and experiencing it are different things completely and many new teachers are not properly prepared for working in the classroom with students.

Classroom management can contribute to a beginning teacher becoming either a good or bad teacher through how well they problem solve or handle situations in the classroom. Suggested reading for classroom management by Dr. Mary C. Clement (2010) recommends: Lee and Marlene Canter's Assertive Discipline (2010) and Succeeding with Difficult Students (1993), Harry and Rosemary Wong's The First Days of School (2009), and Carol Fuery's Discipline Strategies for the Bored, Belligerent, and Ballistic in Your Classroom (1994). When Dr. Clement conducted her research (2002), she found few students could name a writer or theorist in the field of classroom management. Today, there are over 11,000 books on the topic.

Classroom management is not a requirement by some states for teacher certification but should be a part of a requirement for school and universities in preparation for beginning teachers.

\section{Literature Review}

A teaching skill is a set of teaching behaviors of the teacher which is especially effective in bringing about desired changes in pupils' behavior. The name of micro-teaching was coined for this method of developing teaching skills in 1963. The idea of micro-teaching originated for the first time at Stanford University in USA, when an Experimental Project on the identification of teaching skills was in progress under the guidance and supervision of the faculty members (Bush, Allen, McDonald Acheson and many others). This project was aided by Ford Foundation and Kettering Foundation. The team of experts was assigned the development of testing and evaluation tools to measure the attainment of teaching skills. At this juncture Keath Acheson, a research worker was investigating the utility of video tape recorder in the development of technical teaching skills. This instrument could be used for recording the class interaction and the behavior of the trainee vividly and accurately.This lead to the development of a systematic and accurate method of giving feedback to the teacher trainee. All the steps of micro-teaching technique:

$$
\text { Teach } \rightarrow \text { Feedback } \rightarrow \text { Re plan } \rightarrow \text { Re teach } \rightarrow \text { Re feedback. (Shah and Masrur) }
$$

\section{A. Advantage of Microteaching}

Microteaching produces homogenized standard robots with set smiles and procedures. It is said to be a form of play acting unnatural surroundings and the acquired skills may not be internalized. The criticisms lack substance because there is motivation of the teachers to improve himself and also the observer develops an ability to give a good feedback. Repeated experiments have shown that over a period of time microteaching produces remarkable improvement in teaching skills. 


\section{Developing Teachers}

The University of Saskatchewan's study (2010) found beginning teachers found planning and collaboration with other teachers and professional development as the least need of support during their early years of study (Prytula, Hellsten, \& McIntyre, 2010). The University examined two stages of teacher development, pre-service and in-service. It has been found that a change must be made regarding how teacher candidates are taught because universities and schools can teach in the same old way and expect new ideas and ways from new teachers. A continuum of knowledge and learning must be entrenched with a generation of knowledge that has been learned. The practice of collaboration and planning will enhance new teachers learning and student centered practices.

For in-stage service, teachers developing the leadership skill in approaching knowledge and learning in non-traditional ways are important for developing a learning community which consists of an environment of learning, trust, and improvements (Prytula, Hellsten, \& McIntyre, 2010). The move from pre-service to inservice teaching may be difficult and at times lonely with teacher preparation program inadequately preparing beginning teaches with the knowledge, skills, and dispositions requisite to make that transition (Melnick \& Meistger, 2008). It should be noted that the pre-service teaching is done in a controlled classroom environment without any children and does not adequately prepare beginning teachers for their first teaching assignments.

At university and school levels, collaborative action research is important for providing a diverse database for training materials, curricula, and theoretical discussions. which has had a positive effect on beginning teachers improving writing, mathematics, and problem-solving (Mitchell, Reilly, \&Logue, 2008). The development of a community of practice that focuses on collaborative action research enables the beginning teacher to participate in learning relationships. New and creative methods of learning for beginning teachers are encouraged for learning must be continuous. Better teachers cannot be produced using the same old techniques - creativity is important.

\section{The Problem Regarding Teacher Preparation}

The question of effective teacher training programs has always been one of the problems regarding teacher education. This problem arises especially from the following factors:

- The complexity of teaching. (Van Bergeijk, 1971: 11)

- The gap between theory and practice that includes the following:

- There is talk about desirable teaching but practicing it to mastery is omitted.

- Instructing student teachers in desirable teaching activities is too vague and general.

- An effective model, example or exemplar of the desired teaching activity is not always provided. (Borg, Kelly,Langer and Gall, 1974: 24-25).

The objectives of the study were as under:

\section{Objective}

- To understand the current concepts and contents of microteaching to develop teaching competencies.

- To determine the effect of Student Feedback on the Level of Performance of student teachers.

- To develop practice, procedure and internalize the steps involved for effective delivery of the lesson.

- To determine the level of improvement of teaching skill of prospective student in following the microteaching teaching technique

\section{Micro Teacher and Micro Teaching Preparation}

A few minutes of material that teacher especially would like to make sure his students understand by the end of his next class. Teacher should not only plan out how to treat the subject matter, but also give some thought to how he is going to present himself manage the class, and involve the students that's the way the participants find that, along with what they learn from their own experience practice teaching.

\section{RESEARCH METHODOLOGY}

Researchers developed a research question to evaluate the importance and impact of micro teaching for teacher development program.

How could Micro Teaching assist teachers for improving teaching methods outside traditional method? Several authors hinted at how and why such technique could provide extra facilities to the faculties. In order to assess whether all assumptions and expectations rely on solid grounding we have translated several data analysis: 
1. Identify a border range of Micro Teaching

2. How teacher can encourage students to feel their responsibility on the class by micro teaching?

3. How microteaching can aid teacher to accurate class conduct?

4. How microteaching assists to create a method for student reinforcement?

5. How micro teaching improves faculty's presentation skill?

Though we are aware of a very good structured research necessary to work on these objectives, we took advantage of existing teacher's training program run by IUBAT- International University of Business Agriculture and Technology to develop a case study around which to design a very simple two conditions experiment to locate the value of Micro teaching.

\section{Experimental Design}

An action framework developed to conduct the experiment.

The experimental design we adopted consisted of two conditions to be analyzed against two different groups of subjects within each category, one group acting as a control group (condition 1: without feedback of students) and the other one receiving some sort of intervention or treatment (condition 2: in our case, teacher identifies the limitations of his teaching method from video of his class and upgraded the method by feedback of students).

A diagrammatic representation of the experimental design including a comparison between the two experimental conditions 1 and 2 is given below in Figure 2.

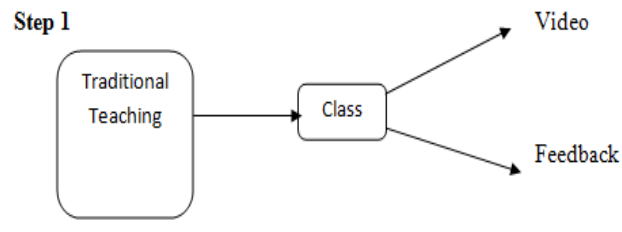

Step 2

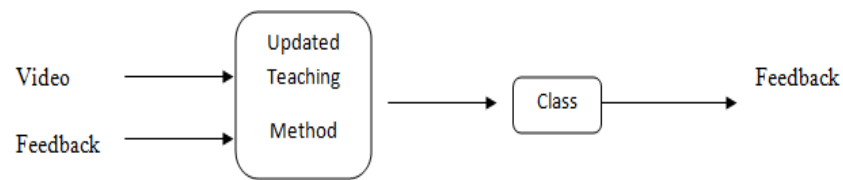

Fig 2: A diagrammatic representation of the experimental design

In this method, sample size was 40. Teacher allocated a group of five students (Total eight groups) where they are assigned to find out the meaning of nonsense words from a paragraph. All of the activities of the class have been recorded through video. After the class, all students gave feedback on a questionnaire. Again, teacher checked the video and fond out the difficulties of students and their lacking of contribution in group work. Based on observation, teacher developed a new method of group work, where students of the group divided the paragraph by few lines and every individual guessed the possible meanings of nonsense word. After finishing all the activities, all group members will discuss about their own findings from the paragraph and checked it as a group.

\section{Results and Discussion}

The results of the experiment are quite satisfactory. All results are given in table below

\section{A.Discussion of Test 1: (Before Micro Teaching)}

\section{Students Skill development according to the lecture session:}

Reading: Out of 7 groups 4 groups were reading this lecture properly and rest 6 of them cannot because the all person were trying to read one things and time was limited. So, they cannot cover.

Listening: They were listening to the instructor because she made a clear direction for how to conduct with this topic

Understanding : Out of 7 groups all group were not understand because the all group were not able to answer the topic and several time they were making the situation that they did not understand what they need to do.

Group Work: Out of 7 groups all group were not capable to do the group work because the work was not divided for individual. They were reading one thing and they were failing to make realization for whole topic Timing: They got 7 minute and all were not able to complete within 7 minute.

\section{Result analysis:}

Table 1: Result Analysis before Microteaching 


\begin{tabular}{|l|l|l|l|l|l|l|}
\hline Five point liker Scale & H1 & H2 & H3 & H4 & H5 & H6 \\
\hline a. strongly agree (5) & 21 & 10 & 19 & 19 & 16 & 10 \\
\hline b. agree (4) & 17 & 25 & 18 & 18 & 20 & 23 \\
\hline c. neutral (3) & 2 & 5 & 2 & 2 & 4 & 5 \\
\hline d. disagree (2) & 0 & 0 & 1 & 1 & 0 & 1 \\
\hline e. strongly disagree (1) & 0 & 0 & 0 & 0 & 0 & 1 \\
\hline Total & 179 & 165 & 175 & 175 & 172 & 160 \\
\hline Average(Sample Mean) & 4.48 & 4.12 & 4.37 & 4.37 & 4.3 & 4 \\
\hline Population Mean & 2.5 & 2.5 & 2.5 & 2.5 & 2.5 & 2.5 \\
\hline Variance & 0.35 & 0.36 & 0.48 & 0.48 & 0.82 & 0.7 \\
\hline Standard Deviation & 0.59 & 0.6 & 0.69 & 0.69 & 0.9 & 0.83 \\
\hline Z- value (cal) & 21.22 & 17.38 & 17.12 & 17.12 & 12.85 & 11.42 \\
\hline Z- value (tab) & 1.96 & 1.96 & 1.96 & 1.96 & 1.96 & 1.96 \\
\hline $\begin{array}{l}\text { Z-cal >Z Tab Null } \\
\text { hypothesis }\end{array}$ & rejected & rejected & rejected & rejected & rejected & rejected \\
\hline
\end{tabular}

1. $52 \%$ respondents strongly agreed with this opinion that the student is aware of his or her responsibility.

2. $62 \%$ respondents agreed with this opinion that the method by faculty aided them to accurate conduct.

3. $47 \%$ respondents strongly agreed about their reinforcement and encouragement in the class.

4. $47 \%$ respondents strongly agreed about the good connection between course content and subject matter.

5. $50 \%$ respondents rated the level of faculty's presentation as excellent.

6. 57\% respondents agreed with this opinion that the text and other learning materials used in this course were effective.

\section{B. Discussion of Test 2: (After Microteaching)}

1. Students Skill development according to the lecture session:

Reading: Out of 7 groups all groups were reading this lecture properly because they were reading one line for one person.

Listening: They were listening to the instructor because he made a clear direction for how to conduct with mind map technique.

Understanding: Out of 7 groups, all groups were understood because the all group were able to answer.

Group Work: Out of 7 groups, all groups were doing group work because the work was divided for individual.

Timing: They got 5 minutes and all were able to complete within 5 minute.

\section{Result analysis:}

Table 2: Result Analysis after Microteaching

\begin{tabular}{|l|l|l|l|l|l|l|}
\hline Five point liker Scale & $\mathrm{H} 1$ & $\mathrm{H} 2$ & $\mathrm{H} 3$ & $\mathrm{H} 4$ & $\mathrm{H} 5$ & $\mathrm{H} 6$ \\
\hline a. strongly agree (5) & 27 & 23 & 22 & 23 & 28 & 22 \\
\hline b. agree (4) & 10 & 15 & 14 & 12 & 9 & 11 \\
\hline c. neutral (3) & 3 & 2 & 3 & 4 & 2 & 5 \\
\hline d. disagree (2) & 0 & 0 & 1 & 1 & 1 & 2 \\
\hline $\begin{array}{l}\text { e. strongly disagree } \\
(1)\end{array}$ & 0 & 0 & 0 & 0 & 0 & 0 \\
\hline Total & 184 & 173 & 177 & 177 & 184 & 173 \\
\hline $\begin{array}{l}\text { Average(Sample } \\
\text { Mean) }\end{array}$ & 4.6 & 4.33 & 4.43 & 4.43 & 4.6 & 4.33 \\
\hline Population Mean & 2.5 & 2.5 & 2.5 & 2.5 & 2.5 & 2.5 \\
\hline Variance & 0.39 & 0.37 & 0.97 & 0.59 & 0.49 & 0.89 \\
\hline Standard Deviation & 0.62 & 0.61 & 0.98 & 0.77 & 0.7 & 0.94 \\
\hline Z- value (cal) & 1.96 & 1.96 & 1.96 & 1.96 & 1.96 & 1.96 \\
\hline Z- value (tab) & 21 & 18.3 & 12.87 & 21.44 & 17.5 & 12.2 \\
\hline $\begin{array}{l}\text { Z-cal >Z Tab Null } \\
\text { hypothesis }\end{array}$ & rejected & rejected & rejected & rejected & rejected & rejected \\
\hline
\end{tabular}


1. Student's awareness of his or her responsibility improved to $67 \%$.

2. $58 \%$ respondents strongly agreed with this opinion that the new method by faculty aided them to accurate conduct.

3. After second test, 55\% respondents felt encouraged and reinforced.

4. According to 57\% respondents improved course contents were delivered in second test which were much related with subject matter.

5. $70 \%$ of total respondents rated the level of faculty's presentation was improved.

6. 55\% respondents strongly agreed that the text and other learning materials used in this course were effective.

\section{Findings of Microteaching:}

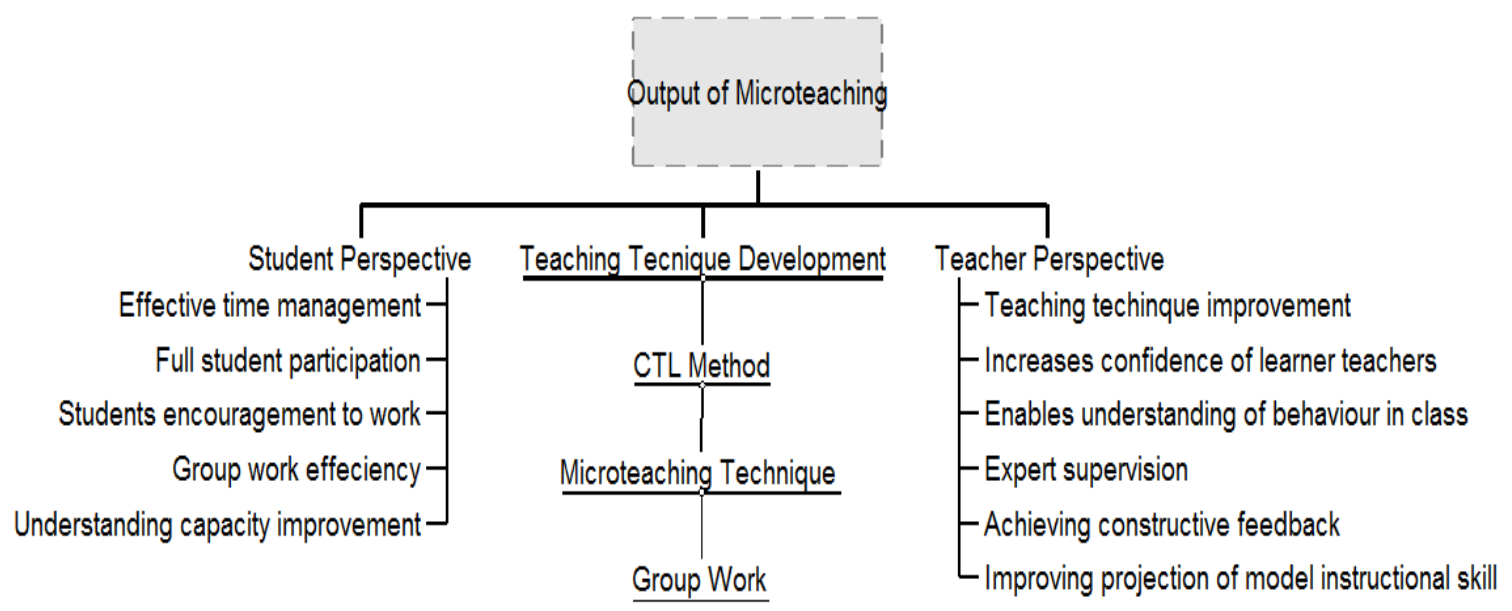

Fig. 3: Output of Microteaching

We found that microteaching used to eliminates some of the complexities of learning to teach in the classroom situation such as the pressure of length of the lecture, the scope and content of the matter to be conveyed, the need to teach for a relatively long duration of time (usually an hour) and the need to face large numbers of students, some of whom are hostile temperamentally.

In fig.3, it was clearly shown, the level of improvement from both student and teachers perspectives. Teaching technique improvements are

1. Individual students' participation (avoid dominating students and encouraging every students' participation)

2. Full participation of all individual group members.

3. Effective uses of time.

4. Constructive feedback from students and efficient group work.

This effective technique can be done through the creation of required course that includes collaboration and journaling as well as the assigned mentor. Video should be done of the teachers teaching and viewed with peers to focus on the particular elements of the lesson or teaching style. Observation may include clarity of lesson explanation, voice, body language and level of group interaction.

\section{Limitations}

To doing this research researcher found some limitation to conduct the whole research analysis. Those are

1. The question of effective teacher training programs has always been one of the problems regarding teacher education.

2. Limitation of the amount of teaching time.

3. Limitation of the number of teaching skills.

4. The amount of learning content is limited.

\section{Conclusion}

The question of effective teacher training programs has always been one of the problems regarding teacher education. To run out this problem the concept of different learning methodology is made. Microteaching is organized practice teaching. The goal is to give instructors confidence, support, and feedback by letting them try out among friends and colleagues a short slice of what they plan to do with their students. The conclusions were drawn according to the main domains of Microteaching: Planning, Set Induction, 
Presentation, Questioning, Encouraging the students to questions, Exemplifications, Communication. The student teachers were very communicative with the planning process used in microteaching. They felt that it was adaptable for normal classroom teaching, focused on specific skills .Microteaching lesson were planned in the way of logical sequence. Students believed that Microteaching encouraged the students in synthesizing information about the topic. It also encouraged a great relationship of motivation and discovers more information between previous and present structured teaching technique. Students also expressed that during the presentation, they felt anxious due to the feeling of being observed. The Microteaching concept is helping the teacher to develop the teaching level and help the students to make the understanding level the critical factor in a short time with more understanding. The concept is developed under a conceptual frame work and applied according to the experimental design by the researcher. The main limitation of microteaching is time limitation but the method is effective for proper understanding.

\section{Reference}

[1]. Dr.K.S.Sujatha "MICRO TEACHING - A VEHICLE OF TEACHER TRAINING"

[2]. Le Maistre, C., \& Paré, A. (2010). Whatever it takes: How beginning teachers learn to survive. Teaching and Teacher Education, 26, 3, 559-564.

[3]. Martin, D., \& Campbell, B. (1999). Managing and participating in group discussion: a microtraining approach to the communication skill development of students in higher education. Teaching in Higher Education, 4, 3, 327-337

[4]. Mastromarino, R. (2004). The use of microteaching in learning the redecision model: A proposal for an observation grid. Transactional Analysis Journal, 34, 1, 37-47.

[5]. Melnick, S. A., \& Meister, D. G. (2008). A comparison of beginning and experienced teachers` concerns. Education Research Quarterly, 31, 3, 39-56.

[6]. Mitchell, S. N., Reilly, R. C., \& Logue, M. E. (2009). Benefits of collaborative action research for the beginning teacher. Teaching and Teacher Education, 25, 2, 344-349.

[7]. Prytula, M. P., Hellsten, L. M., \& McIntyre, L. J. (2010). Perception of teacher planning time: And epistemological challenge. Current Issues in Education, 14, 1, 4-29. Retrieved from http://cie.asu.edu/ojs/index.php/cieatasu/article/view/437

[8]. Shah Hussain Syed Manzoor, Masrur Rehana "IMPACT OF MICRO TEACHING SKILLS ON THE PERFORMANCE OF PARIMARY SCHOOL TEACHERS"

[9]. Sterrett, W. L., \& Imig, S. (2011). Thriving as a new teacher in a bad economy. Kappa Delta Pi Record, 47, 2, 68 -71. 